\title{
Judiciary criticized over French blood trial
}

Paris. The Paris bar association last week warned the French legal system against allowing public opinion to take precedence over the law in its prosecution of individuals accused of supplying haemophiliacs with blood-clotting factors contaminated with HIV in the mid-1980s.

The organization, which represents more than 11,000 barristers, gave its warning after a judge had indicted Michel Garretta, former director-general of the French $\mathrm{Na}$ tional Blood Transfusion Service (CNTS), on the criminal charge of 'poisoning'.

"In the absence of any new element, someone already found guilty cannot be retried for the same acts," the association said. Garretta had already been sentenced to four years in prison for the same acts in 1992, but only in a magistrates court, and on the misdemeanour of 'deception over product quality'.

In a communiqué, the association said that "whatever the respect and compassion which the pain of the victims imposes on everyone, we have the right to expect that the judiciary does not cede to the pressure of public opinion". It added: "Only the law should guide its action."

The current legal confusion stems from a ruling by the Supreme Court of Appeals in June. This upheld Garretta's first conviction, rejecting demands by groups representing haemophiliacs that it be overturned and that new charges of poisoning be brought. But the court also left the door open to the further charges by stating that the acts committed could qualify as poisoning.

The bar association's stand also raises the question of how far public pressure has influenced the judiciary throughout the affair. The association says it would be "inappropriate" to comment on the first trial. But at least one senior official says that pressure from the public and the press have prevented justice from being done.

One aspect of concern is the large number of individuals who shared responsibility in the affair, from government officials to physicians who prescribed products they knew were unsafe. The prosecutor at the first trial remarked that "if there are only four charged, it is that the choice was not between four or five, but between four and 100".

It is clear that CNTS - and Garretta in particular - continued to produce clotting factors contaminated with HIV to avoid importing heat-inactivated products. But there is a widespread impression in France that the four convicted officials are in some sense scapegoats.

Indeed, the lawyer representing Garretta, François Morette, said last week that he intends to bring proceedings against 300 other individuals for their part in distributing contaminated blood products.

Others continue to support Jean-Pierre Allain, the former head of research and development at CNTS. Many scientists feel that his sentence to four years in prison (with two suspended) on the same charges as Garretta was particularly unjust, given that he had opposed the CNTS's policy of not importing heat-inactivated products.

\section{IMAGE UNAVAILABLE FOR COPYRIGHT REASONS}

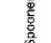
tectionist attitudes, and led to economics being given priority over public health.

Françoise Barré-Sinoussi, for example, a co-discoverer of HIV, has publicly stated that the version of events in 1984 and 1985 as now being described in the media "bore no relation" to the reality facing scientists at the time.

Newspaper articles from 1985 suggest retrospectively that there were enough warning signs in the public domain that blood supplies were contaminated with HIV for the press, the scientific and medical community and haemophiliac groups to have intervened. But, apart from a few individuals, most people failed to recognize the consequences.

Libération, for example, referred in its issue of 8 March 1985 to a study showing that almost one per cent of blood donors in Paris were seropositive, and noted four months later that heat-inactivated blood products were being reserved for seronegative haemophiliacs. But little was made of the issue at the time.

Declan Butler

\section{UK 'should lift superhighway rules'}

London. A House of Commons committee has recommended that the British government should lift a ban on British Telecom (BT) and other telephone companies that prevents them from providing entertainment services on fibre-optic cables.

In a report published last week, the Select Committee on Trade and Industry says that uncertainty over whether the government would lift the ban is holding back investment in a new network designed to act as Britain's 'information superhighway'.

The committee also urged the government to rectify what it described as "the lack of a clear sense of vision or excitement" of the potential for broadband communications in the United Kingdom, and praised the high profile given to developments in the United States and elsewhere.

It has been calculated that the construction of the national fibre-optic network will cost $£ 15$ billion (US\$23 billion) over and above investment already planned by the telecommunications industry.

The committee says that this will be recouped by the boost to the national economy. But BT, which is the largest communications company in Britain, has said that it cannot justify such large expenditure without a guarantee that it can use the network to operate lucrative services such as home shopping, videos on demand, home financial services and interactive video games.

In 1984, the British government introduced a ban restricting national public telecommunications operators from transmitting entertainment services. This was intended to stimulate investment in the cable-television market. The ban is not due to be lifted until 2001 at the earliest. But the committee wants the government to make a clear commitment to lift the ban by the end of 2002.
Maggie Verrall 